\title{
PENERAPAN FORUM ONLINE BULLETIN BOARD PADA SMARTPHONE ANDROID
}

\author{
RIKI $^{1}$ \\ Sekolah Tinggi Manajemen Informatika dan Komputer GICI \\ Komp. Batu Aji Center Park - Simpang Base Camp Telp. 0778391333 Fax 0778394641 , \\ Kota Batam Propinsi Kepulauan Riau, Indonesia \\ email: riki.yasril@gmail.com
}

\begin{abstract}
Abstrak
Penerapan forum kedalam dunia internet dapat di implementasikan menggunakan myBB, kemudahan dari fitur myBB dapat membetuk forum dan mengatur forum sesuai kategori yang dibutuhkan. Fitur-fitur yang ada di myBB juga dapat membentuk bulletin board berupa pengumuman . Dengan berkembangpesatnya teknologi informasi sekarang ini, forum tidak hanya di akses sebatas dari komputer pribadi, namun juga telah berhasil diterapkan di smartphone. Android adalah merupakan salah satu sistem operasi smartphone yang bersifat opensource dan mudah dikembangkan untuk membangun aplikasi forum Fakultas Teknik Universitas Maritim Raja Ali Haji. Dan dibangun aplikasi untuk mengakses forum dengan platform android, pembangunan aplikasi android diperuntukan sebagai sisi client dan myBB ditujukan untuk web server. Dengan skema rancangan dua rancangan pembuatan aplikasi tersebut, adapun teknik pembuatan aplikasi tersebut dengan myBB, layanan buzztouch serta eclipse yang telah didukung dengan ADT (Android Development Tools), maka dilakukan pengembangan sistem menggunakan metode waterfall sebagai tahapan pembangun aplikasi client server untuk dapat melakukan akses ke forum dan telah dapat diterapkan di Forum Fakultas Teknik Universitas Maritim Raja Ali Haji.
\end{abstract}

Kata Kunci: Aplikasi Android, Forum, Bulletin Board, Smartphone

\section{PENDAHULUAN}

Ajang diskusi acapkali dibutuhkan untuk mendapatkan sesuatu kesimpulan, pengertian, sumber informasi, penjelasan, pengumuman maupun kesepakatan. Dibutuhkan media ataupun wadah untuk menetapkan itu, dan perantara tersebut dibentuk kedalam forum. Forum berperan penting terhadap meadiasi pertukaran informasi di dalam dunia pendidikan.

Terutama diterapkan kedalam lingkungan komunitas tertentu seperti kedalam universitas khususnya Fakultas Teknik Universitas Maritim Raja Ali Haji.
Kemungkinan yang dapat diefesiensikan dari forum ini menjadikan akses ke dalam forum dengan situasi yang tidak diwajibkan bertatap muka, artinya diskusi forum bisa dilakukan dimanapun tentunya dengan akses internet sebagai jembatannya kemajuan teknologi tidak membuat akses internet terpaku kepada pengguna komputer, namun dapat diakses melalui perangkat smartphone. Android merupakan salah satu sistem operasi smartphone yang bersifat gratis dan mudah dikembangkan untuk membangun aplikasi
JURSIMA

Jurnal Sistem Informasi dan Manajemen https://ejournal.giciku.ac.id/

STMIK GICI 
forum Fakultas Teknik Universitas Maritim Raja Ali Haji. Sebagai bahan pertimbangan dalam penelitian ini akan dicantumkan beberapa hasil penelitian terdahulu antara lain:

A'la Syauqi dan Maret Dewi pada tahun 2011 melakukan penelitian mengenai Rancang Bangun Aplikasi Mobile Learning pada Sistem Operasi Android. Tujuan dari penelitian ini adalah untuk menjadikan mobile learning sebagai salah satu alternatif untuk memecahkan permasalahan dalam bidang pendidikan, terutama masalah pemerataan akses infomasi pendidikan, kualitas konten pembelajaran yang berupa materi pembelajaran. Mobile learning memiliki keterbatasan sumber daya dan keragaman platform sehingga diperlukan rancangan yang mampu menjamin kompalitibilitas dan inteoperabilitas.

Dalam penelitian ini melakukan metode analisis permasalahan sistem dengan memperhatikan keterbatasan resource, hardware, device yang pervasive, skema intregrasi, dan kenyamanan pengguna. Sedangkan analisis sistemnya sendiri merancang dua pembuatan di sisi server dan di sisi client dalam bentuk layanan mobile, disisi client yang bertugas untuk mengakses ke server.

Penelitian lain dilakukan oleh Arya Pradana (2011) menyimpulakan koneksi antara web server dan aplikasi mobile di android telah berhasil diimplementasikan dengan menggunakan metode http request dan response.

Dalam penelitian yang dilakukan Sung Kiwoon, Srinivasan dan Schulzrinne (2010) menyimpulkan bahwa Forum dan bulletin board adalah wadah tentang kejadian dan informasi umum yang mungkin akan menarik bagi rekanrekannya. Siswa dapat berbagi informasi tentang pengetahuan maupun berita yang terjadi di seluruh kampus.
Newsgroup dan web berbasis forum menjadi cepat terkenal di internet, menyediakan sebuah forum online.

Kohei Arai dan Herman Tolle (2011) mengadaptasi komposit berbasis PC $e$ learning halaman web dan mengirimkannya ke perangkat mobile melalui ponsel. Sebuah halaman web elearning komposit kandungan e-learning yang terdiri dari pembelajaran objek.

Steele, J. (2011) Android merupakan sistem operasi yang dikembangkan oleh google dengan berbasis kernel linux versi 2.6 dan berbagai perangkat lunak dari GNU yang bersifat opensource. Keunggulan utama android yang bersifat opensource, membuat smartphone android di jual lebih murah dibandingkan dengan Blackberry, atau iPhone meski fitur (hardware) yang ditawarkan android lebih atraktif dan ini membuat semakin digandrungi smartphone dengan sistem operasi jenis android ini.

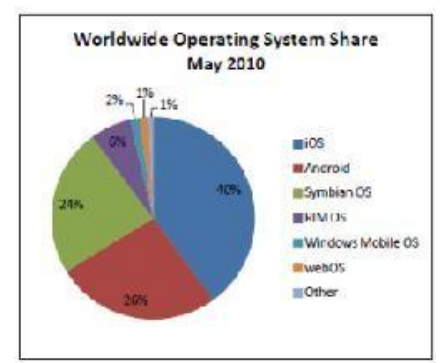

Gambar 1 Pangsa pasar sistem operasi bulan mei 2010

Menurut Fadjar Efendy Rasjid (2010) android adalah software untuk perangkat mobile mencakup sistem operasi, middleware dan aplikasi kunci. Pengembangan aplikasi pada platform android menggunakan bahasa pemrograman java. Serangkaian aplikasi inti android antara lain client email, program sms, kalender, peta, browser, kontak dan lain-lain. Android bersifat opensource, pengembangan android mampu membangun aplikasi secara 
inovatif. Android berbasis pada versi Linux 2.6 untuk layanan sistem inti seperti keamanan, manajemen memori, manajemen proses, network stack dan model driver.

Terdapat dua jenis distributor sistem operasi android di dunia yaitu pertama yang mendapat dukungan penuh dari google atau google mail server (GMS) dan kedua adalah yang benar-benar bebas distribusinya tanpa dukungan langsung google atau dikenal sebagai open handset distribution (OHD).

Dengan konsep mengemas 2 sisi rancangan dengan membangun website menggunan forum engine myBB sebagai webservernya dan disisi kedua dibangun aplikasi dari perangkat android sebagai sisi client. Kemasan sisi client dirangkai melalui layanan buzztouch. Dari sisi client, pengguna mengakses ke website forumnya.

Tentunya harus ada langkah menerapkan forum ini kedalam perangkat smartphone android melalui tahapantahapan pengembangan model sistem dengan menggunakan metode waterfall. Metode waterfall merupakan metode klasik dari pengembangan suatu sistem, pendekatan waterfall memungkinkan prediksi terhadap lamanya waktu penyelesaian proyek dengan memperhatikan kemungkinan iterasi ke tahap sebelumnya sehingga efektivitas pengembangan proyek dapat ditingkatkan.

\section{METODE PENELITIAN}

Dengan menentukan objek penelitian dan lokasi dari fokus penelitian dilakukan di Fakultas Teknik Universitas Maritim Raja Ali Haji, khususnya teknik perangkat lunak, batam -Kepulauan Riau. Selain lokasi objek dibutuhkan tahap analisa kebutuhan.
Requirement yang diperlukan seperti jenis data yang di butuhkan dan metode pengumpulan data dengan metode dokumen dan observasi serta perancangan dan seleksi sistem termasuk implementasi, pengujian dan pemeliharan.

\section{A. Pemodelan Waterfall}

Teknik air terjun yang meneliti kebutuhan sistem, mencang dan menyeleksi, implementasi pegujian dan pemeliaharaan diceritakan dalam deskripsi berikut.

Objek peneleitian telah ditentukan sesi berikutnya sistem Membutuhkan data, data tesebut diambil dengan metode dokumen dan observasi. Dokumen yang diambil berupa nama-nama, nip dan nim dari ketiga kategori pengguna yaitu admin, lecture, dan student

\section{Perancangan}

Kemudian perancangan \& seleksi sesuai dengan tema forum UMRAH sebagai wadah diskusi online bagi komunitas perguruan tinggi UMRAH. Maka perlu di rancang kategori topik yang diusung mewakili tema forum, adapun perancangan katergori forum sebagai berikut:

\section{Forum UMRAH}

Merupakan kategori yang berisikan informasi perkuliahan mengenai Forum UMRAH.

Adapun forum yang dicakup dalam kategori Forum UMRAH adalah:

a. Pratikum

Forum yang ditujukan untuk topik mengenai informasi jadwal pratikum di lab UMRAH 
b. Konsultasi TA (tugas akhir)

Forum ini untuk diskusi tentang tugas akhir berupa tanya jawab terhadap moderator dalam hal ini dosen.

c. Perkuliahan

Forum ini ditujukan untuk diskusi tentang perkuliahan berlaku untuk seluruh mahasiswa.

\section{Forum UMUM}

a. Penerimaan Mahasiswa Baru

Forum ini di fungsikan untuk melihat pengumuman- penguman tentang informasi penerimaan mahasiswa baru.

b. Dunia Pendidikan

Forum ini di harapkan bisa mendapatkan informasi tentang dunia pendidikan baik kontribusinya seluruh mahasiswa dosen maupun dekan yang ingin memberikan informasi.

3. Forum Kemahasiswaan

Badan Eksekutif Mahasiswa (BEM)

Forum ini dimanfaatkan untuk Kemahasiswaan yang memiliki kegiatan di BEM

4. Rule \& Saran

a. Peraturan \& etika

Forum ini menjelaskan tata etika dalam berforum

b. Timbal Balik

Forum ini berupa saran atau komentar dari user untuk kemajuan forum.

Menyeleksi kebutuhan apa saja yang di perlukan di forum online bulletin board ini, seperti pembagian fasilitas terhadap tiap-tiap user. Dimana forum memiliki 4 kategori pengguna. Admin, Dosen (setara moderator), Mahasiswa dan Tamu

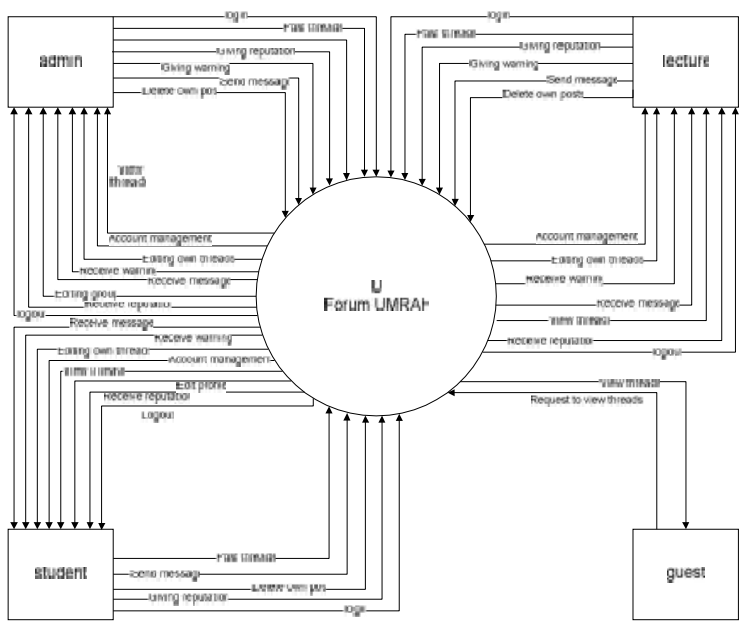

Gambar 2.1 DFD level 0 myBB

\section{Keterangan:}

1. Admin merupakan pengguna yang memiliki wewenang pengaturan di dua sisi aplikasi yaitu disisi web server dan aplikasi, mengelola forum sesuai kebutuhan termasuk menjaga keamananforum

2. Lecture adalah pengguna yang memiliki kontribusi yang cukup penting demi kelancaran forum, memonitor forum, memberikan informasi, solusi, menjaga forum lebih kepada moderator forum.

3. Student adalah pengguna yang memiliki akses berdikusi dalam forum, tidak dituntut hanya untuk memperoleh informasi. Dianjurkan juga memberikan informasi untuk menjadikan bahan diskusi.

4. Guest pengguna yang sebatas melihat informasi.

Selanjutnya pengembang forum ini dilakukan dengan forum engine myBB setelah melakukan penyeleksian, kemudian tahapan berikutnya melakukan pengisian content- content yang telah ditentukan sebelumnya. Dibutuhkan 
penginstalan di forum myBB berupa konversi ke perangkat mobile berupa plugin gomobile, kemudian di design plugin tersebut sesuai kebutuhan seperti yang ditampilkan gambar berikut

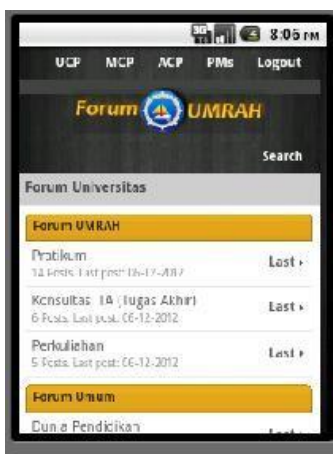

Gambar 2.2. Home Forum dari platform Android

Halaman ini sebagai halaman home dari forum online bulletin board.

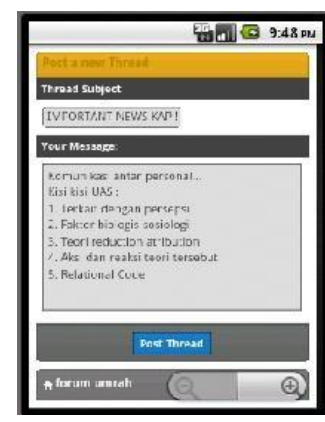

Gambar 2.3. Post thread dari platform Android

Proses dimana pengguna melakukan posting thread kedalam forum, dengan mengisi subjek da isi pesan posting.

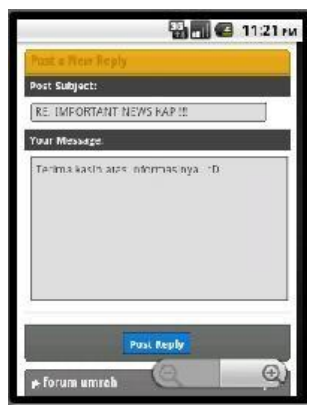

Gambar 2.4. Post replay dari platform
Isi dari posting-an thread di replay dalam penamaan post replay. Dengan demikian topik yang dibuat dapat mendapatkan komentar dari pengguna yang namun tidak diperuntukan untuk pengumuman.

\section{Pengujian}

Pengujian dilakukan untuk mengetahui informasi tentang kegunaan produk dan juga kualitas produk. Dan objektifitas perangkat lunak memungkinkan para pengguna untuk mengerti menghargai dan memahami resiko ketika menjalankan aplikasi. Aplikasi penguji tergantung pada metode penguji yang digunakan, bisa diterapkan ketika dibuat.

\section{a. Pengujian Alpha Testing}

Pengujian dilakukan guna mengetahui informasi tentang forum apakah dapat berjalan dengan baik di aplikasi, kemudian dapat melakukan diskusi sebagaimana mestinya dengan melakukan post thread dan post replay di kategori forum. Dalam hal ini, dilakukan pengujian pada.

\section{Login Admin}

\begin{tabular}{|l|l|}
\hline \multicolumn{2}{|c|}{ Kasus Data dan Hasil Uji (Data } \\
\hline Data masukan & $\begin{array}{l}\text { Username: admin. } \\
\text { Data yang } \\
\text { dimasukkan benar } \\
\text { kemudian tekan } \\
\text { diharapkan }\end{array}$ \\
\hline Putton login, lalu \\
\hline Kengamatan & Menampilkan \\
\hline \multicolumn{2}{|c|}{ Kasus Data dan Hasil Uji (Data } \\
\hline Data masukan & Username: admin, \\
\hline $\begin{array}{l}\text { Yang } \\
\text { diharapkan }\end{array}$ & $\begin{array}{l}\text { Tampil pesan } \text { error } \\
\text { username } \text { atau }\end{array}$ \\
\hline
\end{tabular}


Volume 5 No. 1

Mei 2017

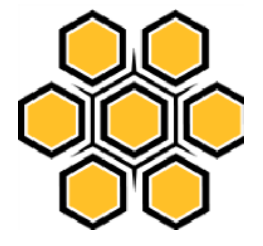

\begin{tabular}{|l|l|}
\hline \multirow{2}{*}{ Pengamatan } & $\begin{array}{l}\text { Muncul pesan } \text { error: } \\
\text { "You have entered an } \\
\text { invalid } \\
\text { usernamelpassword } \\
\text { combination. } \\
\text { If you forgotten }\end{array}$ \\
\hline Kesimpulan & Diterima \\
\hline
\end{tabular}

Tabel 2.1. Pengujian Form Login Admin

Untuk login dari sisi lecture dan student memiliki hasil pemberitahuan yang sama jika memberikan username dan pasword kombinasi yang salah.

2. Post thread

\begin{tabular}{|c|c|}
\hline \multicolumn{2}{|c|}{ Kasus Data dan Hasil Uji (Data Normal) } \\
\hline $\begin{array}{l}\text { Data } \\
\text { masukan }\end{array}$ & $\begin{array}{l}\text { Thread subject dan } \\
\text { message thread }\end{array}$ \\
\hline $\begin{array}{c}\text { Yang } \\
\text { diharapkan }\end{array}$ & $\begin{array}{l}\text { Data yang dimasukkan } \\
\text { benar kemudian tekan } \\
\text { button post thread, } \\
\text { kemudian thread akan } \\
\text { tampil di kategori forum. }\end{array}$ \\
\hline Pengamatan & $\begin{array}{l}\text { Menampilkan thread } \\
\text { yang sudah di posting. }\end{array}$ \\
\hline Kesimpulan & Diterima \\
\hline \multicolumn{2}{|c|}{ Kasus Data dan Hasil Uji (Data Salah) } \\
\hline $\begin{array}{c}\text { Data } \\
\text { masukan }\end{array}$ & $\begin{array}{l}\text { Thread subject dan } \\
\text { message thread }\end{array}$ \\
\hline $\begin{array}{c}\text { Yang } \\
\text { diharapkan }\end{array}$ & $\begin{array}{c}\text { Tampil pesan error jika } \\
\text { salah satu thread subject } \\
\text { maupun message thread } \\
\text { tidak di isi. }\end{array}$ \\
\hline Pengamatan & $\begin{array}{l}\text { Muncul pesan error: } \\
\text { "The subject is missing. } \\
\text { Please enter a subject } \\
\text { The Message is missing. } \\
\text { Please enter a message" }\end{array}$ \\
\hline Kesimpulan & Diterima \\
\hline
\end{tabular}

Tabel 2.2. Pengujian Form Post thread

\section{Keterangan:}

Setelah navigasi kategori forum dituju kemudian posting thread dapat dilakukan dengan ketentuan thread subject harus diisi dan message thread, pesan error muncul kedua-duanya jika kedua field tidak diisi di form untuk melakukan posting thread

\section{Delete thread}

\begin{tabular}{|c|c|}
\hline \multicolumn{2}{|c|}{ Kasus Data dan Hasil Uji (Data Normal) } \\
\hline Tindakan & Centang kotak dialog \\
\hline $\begin{array}{l}\text { Yang } \\
\text { diharapkan }\end{array}$ & 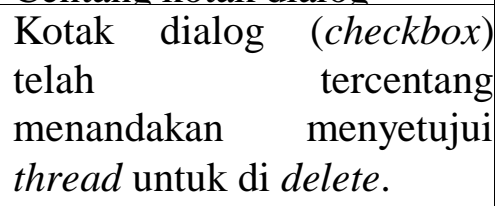 \\
\hline Pengamatan & $\begin{array}{l}\text { Menghilangkan thread yang } \\
\text { sudah tercentang. }\end{array}$ \\
\hline Kesimpulan & Diterima \\
\hline \multicolumn{2}{|c|}{ Kasus Data dan Hasil Uji (Data Salah) } \\
\hline Tindakan & Tidak tercentang \\
\hline $\begin{array}{l}\text { Yang } \\
\text { diharapkan }\end{array}$ & $\begin{array}{l}\text { Tampil pesan error jika } \\
\text { kotak dialog untuk } \\
\text { delete tidak dicentang. }\end{array}$ \\
\hline Pengamatan & $\begin{array}{l}\text { Muncul pesan error: "The } \\
\text { post was not detected } \\
\text { because you didn't check } \\
\text { 'Delete" checkbox" }\end{array}$ \\
\hline Kesimpulan & Diterima \\
\hline
\end{tabular}

Tabel 2.3. Pengujian Delete thread

Hasil uji untuk melakukan delete thread dapat dilakukan jika checkbox kotak centang telah di centang menandakan thread disetujui untuk di delete, jika tidak dicentang kotak centang tersebut maka thread tersebut tidak terhapus, untuk delete replay pada dasarnya sama dengan delete thread proses untuk melakukan delete-nya juga harus mencetang dari checkbox yang ada. 
Volume 5 No. 1

Mei 2017

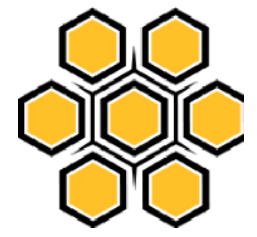

Selanjutnya pengujian juga dilakukan pada tahap design, design yang di bangun di peruntukan untuk kategori resolusi

\begin{tabular}{|l|l|l|l|}
\hline No & $\begin{array}{l}\text { Kepada } \\
\text {-tan }\end{array}$ & Dibangun di & $\begin{array}{l}\text { Kenya- } \\
\text { manan }\end{array}$ \\
\hline 1 & 120dpi & $\begin{array}{l}\text { QVGA } \\
(240 x 320)\end{array}$ & $\sqrt{ }$ \\
\hline 2 & $240 d p i$ & $\begin{array}{l}\text { WVGA800 } \\
(480 x 800)\end{array}$ & - \\
\hline 3 & 120dpi & $\begin{array}{l}\text { WQVGA432 } \\
(240 x 432)\end{array}$ & $\sqrt{ }$ \\
\hline 4 & 160dpi & $\begin{array}{l}\text { HVGA } \\
(320 x 480)\end{array}$ & $\sqrt{ }$ \\
\hline 5 & 120dpi & $\begin{array}{l}\text { WQVGA400 } \\
(240 x 400)\end{array}$ & $\sqrt{ }$ \\
\hline 6 & 240dpi & $\begin{array}{l}\text { WVGA854 } \\
(480 x 854)\end{array}$ & - \\
\hline
\end{tabular}

Tabel 2.4. Pengujian Kenyamanan Desain

Uji coba terhadap kepadatan resolusi membuktikan aplikasi ini tidak mendukung kenyamanan tampilan ke tiaptiap kepadatan, seperti dijabarkan tabel pengujian kenyamanan design untuk kepadatan diatas 160 dpi kenyamanan tampilan tidak mendukung.

\section{b. Kesimpulan Hasil Uji Pendekatan} Alpha Testing

Dari hasil pengujian dengan alpha testing yang telah dilakukan dapat ditarik kesimpulan bahwa aplikasi forum online sudah berjalan sebagaimana diharapkan tetapi tidak menutup kemungkinan dapat terjadi kesalahan pada suatu saat aplikasi digunakan seiring waktu penggunaan dari aplikasi ini.

\section{ANALISIS DAN PEMBAHASAN}

\section{Analisis Proses Pengembangan}

Proses pengemangan aplikasi ini memiliki dua tahap dari tahap pengerjaan situs web-nya dan pembuatan aplikasi di client androidnya . skup yang di bahas ada 2 jadi di rincikan satu-satu, dimulai dari proses pengembangan di situs webnya yaitu membuat forumnya. Proses pengembangan forum ini juga memiliki beberapa langkah pengembangan yang perlu dilalui; pertama langkah-langkah pemasangan forum engine ini di situs webnya terlebih dahulu.

runtutan proses pemasangan:

1. Memilih hosting digunakan untuk pembangunan web forum

2. unggah software myBB

3. Proses pemasangan sama seperti proses pemasangan $\mathrm{cms}$ lainnya. Unggah ke dalam berkas root

4. Setelah itu isi kebutuhan forum dan design sesuai kebutuhan untuk mengelola forum di forum management pada home admin.

5. kebutuhan data pengguna dan bahan informasi dimasukan kedalam sistem

6. Atur group sesuai kebutuhan berdasarkan tipe pengguna.

Untuk tahap pengembangan di sisi kliennya juga memiliki beberapa tahap pengembangan yang harus dilalui.

pertama pengembangan harus memiliki 3 kompenen yang sangat penting yaitu eclipse, ADT plugins dan SDK (software development kit). 
Untuk mengembangkan aplikasi ini tidak cukup dengan komponen eclipse sendiri, dengan eclipse belum bisa membangun aplikasi android. Agar bisa membangun aplikasi android perlum memasang plugin ADT (Android Development Tools) didalam eclipse. Sampai tahap ini eclipse sudah bisa digunakan namun belum dilengkapi library dan emulator, dan untuk memenuhinya butuh 1 komponen lagi yaitu komponen SDK(Software Develompent Kit). SDK sendiri adalah komponen yang ditugaskan sebagai emulator.

Hal yang perlu diperhatikan dalam memasang ADT kedalam eclipse

- Pilih menu help temukan "Install new software"

- Di area Work with tambahkan "https://dlssl.google.com/android/eclipse/", di area Location dan untuk area di namanya boleh diisi bebas.

- Pastikan 4 versi item dalam kotak centang developer tools ada yaitu Android DDMS, Android Development Tools, Android Hierarchy Viewer, Android Traceview.

\section{Pembahasan Proses Kerja Sistem}

Berikut penjelasan yang dibahas, menyangkut kegiatan pengguna dalam sisi klien membuat post dimana pengguna menggunakan media platform android dalam melakukan kegiatan ini. Dalam membahas kegiatan ini, maka terlebih dahulu dibahas dari sisi akses melalui android, kemudian untuk seorang dapat mengakses forum, maka terlebih dahulu pengguna tersebut sudah mendapatkan akun dari admin forum, dan untuk seterusnya pengguna dapat masuk ke dalam forum dan membuat thread maupun memberi komentar atas thread yang ada.

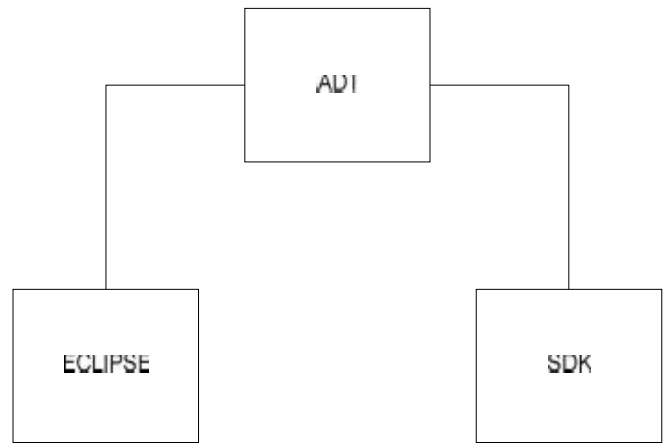

Pada sisi klien pengguna android, dibuatkan aplikasi untuk dapat mengakses forum melalui koneksi internet, dimana memanfaatkan layanan buzztouch, dimulai pada program BT_activity_root java dalam paket com.umrahbetaversions.

Daur hidup untuk menjalankan suatu activity pertama kalinya diperlukan methods OnCreate( ). OnCreate ( ) merupakan dimana view yang ingin ditampilkan di buat, membuka data file, maupun meinginisialisasi activity.

Saat memanggil OnCreate, framework android melewati sebuah bundle objek yang mengandung state activity yang disimpan ketika activity pertama berjalan. Tugasnya memanggil loadAppData, sementara loadAppData menggerakkan thread dar

LoadAppDataWorkerThread,

kemudian LoadAppDataWorkerThread melakukan konfigurasi data, data yang di konfigurasi berupa konfigurasi filename yaitu berupa file dengan format ' $\mathrm{xt}$ '

Adapun file BT_config yang dipanggil menggunakan format JSON

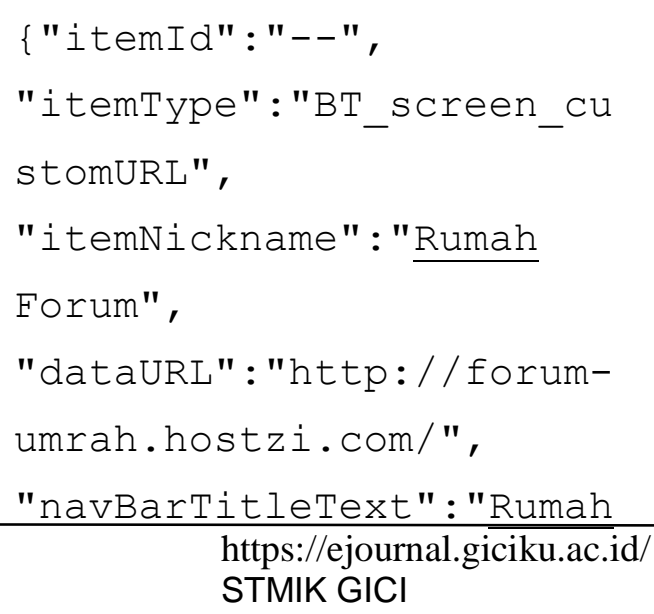


Forum",

"forceRefresh":"1"\},

$\{$ "itemId":"--",

"itemType":"BT"placeCall",
"itemnickname":"Call Us",
"number":",

Setelah

umrahbetaversions_appDelegate

menghubungkan dengan file BT_config

tadi

selanjutnya

umrahbetaversions_appDelegate

menyerahkan proses eksekusi ke

BT_application. Barulah di debug oleh tugasnya BT_application.

BT_application memanggil 2 komponen penggerak aplikasi

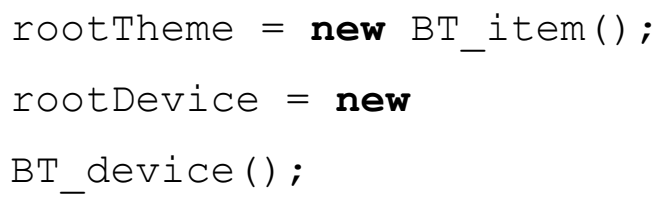

Class BT_item memuat pengaturan aplikasi baik dari item-item apa yang digunakan semuanya di atur disini berikut semua item yang terdata dalam sifat class BT_item; itemIndex, itemId, itemNickname, dan itemType. kemudian class BT_user memuat pengaturan pengguna aplikasi dan Class BT_device merupakan class yang memuat pengaturan dasar alat, semua pengecekan yang ada di alat dari mulai model, versions, tipe koneksi, lebar, tinggi, ScreenDensity dan mengecek kemampuan lainnya. Kemudian BT_application ini melakukan pemuatan tampilan sebagai berikut:

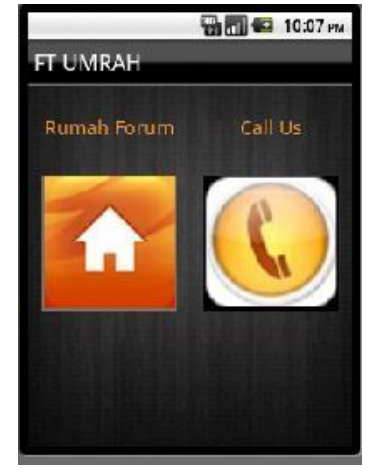

Gambar 4.7. Konfigurasi Eclipse

Sampai disini platform android sudah bisa mengakses keseluruhan content dalam forum. Selanjutnya adalah penjabaran dalam di sisi situs web-nya dimulai dari Admin melakukan login.

\section{KESIMPULAN}

1.Penerapan Forum Online Bulletin Board dalam Platform Android berhasil diterapkan dengan menggunakan metode waterfall untuk forum komunitas FT UMRAH Batam.

Saran

1.Sistem ditambahkan dengan fasilitas untuk memindahkan thread

2.Sistem ditambahkan fasilitas untuk mengunggah file

3. Sistem dibuat kenyamanan resolusi cocok untuk semua platform

\section{UCAPAN TERIMA KASIH}

Fakultas Teknik Universitas Maritim Raja Ali Haji di Batam 


\section{DAFTAR PUSTAKA}

Amiral, M. 2009.Analisis dan implementasi Forum Diskusi menggunakan phpBB 3.04 di PDSI ITI, Institut Teknologi Indonesia

Amri. 2011. Pengertian Content Management System (CMS), http://kentos.web.id (Diakses Tanggal 9 Desember 2011)

Anonim, "Android Developers - Webview Android Developers", http://developer.android.com/reference/an droid (diakses tanggal 16 Desember 2011)

Anonim, “developer mysql -

Developers" MyISAM | Mysql

http://dev.mysql.com/doc/refman/5.6/en/ myisam-storage- engine.html (diakses tanggal 20 mei 2012)

Arai, K, Herman, T. 2011. Module Base Content Adaptation of Composite ELearning Content for Delivering to Mobile Learners, No.3, Vol. 3, halaman 382-387

Arifin, M.Z. 2012. Sistem informasi geografis untuk fasilitas perguruan tinggi berbasis android di kota Surabaya, Institut Teknologi Sepuluh November

Ariq, H. 2010. Web Sever. www.scribd.com/doc/54917409/Pengertia n-Web-Server (diakses tanggal 27 desember 2011)

Haryanto, A . Belajar membuat menu pada android.

http://agusharyanto.net/wordpress/?p=335

. (diakses tanggal 1 maret 2012)

Hermawan, Y. Lab Android Tutorial. www.omayib.com. (diakses tanggal 14 februari 2012)
Khusna T.A.S. 2009. Ujian Online pada mata kuliah matematika diskret berbasis web, Universitas Diponogoro.

Meier, R. 2009. Professional Android Application development, Indianapolice, Indiana

PK.Ragunath, Ravimohan R, S. Velmourougan, 2010. Evolving A New Model (SDLC Model-2010) For Software Development Life Cycle (SDLC), Pondicherry University, India

Poetra, A.2003. Tutorial Cascading Style Sheet (CSS),Ilmu Komputer, halaman 122

Powell, G. 2006. Beginning Database Design . Wiley Publishing, halaman 391393

Pradana, A. 2011. Aplikasi Bulletin Board Berbasis Android, Fakultas Teknik Teknologi Informasi, Institut Teknologi Sepuluh November

Rangevik, A. 2011. A proposal for Android-based tablet client used in one-toone computing in teaching environments, Departement of Information Technology,University of UPPSALA

Rasjid, Fadjar Efendy. 2010 Android : Sistem Operasi pada Smartphone. www.ubaya.ac.id (diakses tanggal 2 desember 2011)

Steele, James. 2011. The Android Developer's Cookbook Building Applications with the android SDK, Addison Wesley

Stephanus H,S. 2011. Mudah membuat aplikasi android, ANDI, halaman 10 
ISSN 2338-1523

E-ISSN 2541-576X

Volume 5 No. 1

Mei 2017

Sung, K, Srinivasan, S, Schulzrinne, H. 2010. BBS- ONE:Bulletin Board and Forum System for Mobile Opportunistic Network, The Faculty of the Graduate School of Computer Science, University of Florida, USA

Syauqi. A, Maret Dewi. K. 2011. Rancang Bangun Aplikasi Mobile Learning Pada Sistem Operasi Android, Universitas Islam Negeri, Malang. 